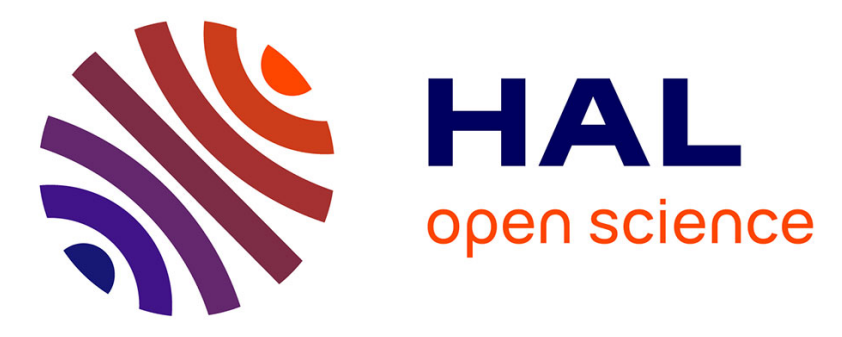

\title{
Tomato chlorotic mottle Guyane virus: a novel tomato-infecting bipartite begomovirus from French Guiana
}

Jean-Michel Lett, Alexandre de Bruyn, Murielle Hoareau, Alassane Ouattara, Sohini Claverie, Anne Dalmon, Damien Laplace, Pierre Lefeuvre, Bruno Hostachy

\section{To cite this version:}

Jean-Michel Lett, Alexandre de Bruyn, Murielle Hoareau, Alassane Ouattara, Sohini Claverie, et al.. Tomato chlorotic mottle Guyane virus: a novel tomato-infecting bipartite begomovirus from French Guiana. Archives of Virology, 2015, 160, pp.2887-2890. 10.1007/s00705-015-2558-0 . hal-01261867

\section{HAL Id: hal-01261867 https://hal.science/hal-01261867}

Submitted on 25 Jan 2016

HAL is a multi-disciplinary open access archive for the deposit and dissemination of scientific research documents, whether they are published or not. The documents may come from teaching and research institutions in France or abroad, or from public or private research centers.
L'archive ouverte pluridisciplinaire HAL, est destinée au dépôt et à la diffusion de documents scientifiques de niveau recherche, publiés ou non, émanant des établissements d'enseignement et de recherche français ou étrangers, des laboratoires publics ou privés.

$$
\text { Copyright }
$$




\title{
Tomato chlorotic mottle Guyane virus: a novel tomato-infecting bipartite begomovirus from French Guiana
}

\author{
Jean-Michel Lett ${ }^{1}$ (1) $\cdot$ Alexandre De Bruyn ${ }^{1,2} \cdot$ Murielle Hoareau $^{1} \cdot$ \\ Alassane Ouattara ${ }^{2} \cdot$ Sohini Claverie $^{2} \cdot$ Anne Dalmon $^{3}$ - Damien Laplace ${ }^{4}$. \\ Pierre Lefeuvre $^{1} \cdot$ Bruno Hostachy $^{5}$
}

Received: 23 June 2015/Accepted: 27 July 2015/Published online: 9 August 2015

(C) Springer-Verlag Wien 2015

\begin{abstract}
This is the first description of the complete genome sequence of a new bipartite begomovirus isolated from tomato (Solanum lycopersicum) in French Guiana, for which we propose the tentative name "tomato chlorotic mottle Guyane virus" (ToCMoGFV). DNA-A and -B nucleotide sequences of ToCMoGFV are only distantly related to known New World begomoviruses. They share the highest nucleotide sequence identity of $80 \%$ with the Brazilian isolates of macroptilium yellow spot virus (MacYSV) and $73 \%$ with soybean chlorotic spot virus (SBCSV). Phylogenetic analysis demonstrated that this novel virus belongs to a new lineage of New World bipartite begomoviruses. The discovery of this new virus confirms the high genetic diversity of begomoviruses in Latin America.
\end{abstract}

Electronic supplementary material The online version of this article (doi:10.1007/s00705-015-2558-0) contains supplementary material, which is available to authorized users.

Jean-Michel Lett

lett@cirad.fr

1 CIRAD, UMR PVBMT, Pôle de Protection des Plantes, 7 Chemin de l'IRAT, 97410 Saint-Pierre, Ile de La Réunion, France

2 Université de La Réunion, UMR PVBMT, Pôle de Protection des Plantes, 7 Chemin de l'IRAT, 97410 Saint-Pierre, Ile de La Réunion, France

3 INRA, UR Abeilles et Environnement, Domaine Saint-Paul, 228 route de l'Aérodrome, CS40509,

84914 Avignon Cedex 9, France

4 DAAF de Guyane, Service de l'alimentation, BP 5002, 97305 Cayenne Cedex, France

5 ANSES-LSV Réunion, Pôle de Protection des Plantes, 7 Chemin de l'IRAT, 97410 Saint-Pierre, La Réunion, France
Begomoviruses (genus Begomovirus, family Geminiviridae) are a group of plant viruses that are transmitted by the whitefly Bemisia tabaci (Aleyrodidae) and are responsible for serious diseases in a wide range of cultivated crops, including tomato (Solanum lycopersicum) (for review, see ref. [13]). In the last two decades, a diverse group of indigenous begomoviruses, commonly known as New World (NW) begomoviruses, has emerged as a major threat to tomato production in Latin America $[1,5,6,11,12]$. Except for the recently described indigenous monopartite virus tomato leaf deformation virus (ToLDeV) in Ecuador and Peru [9], all indigenous NW begomoviruses have a bipartite genome (two DNA components, each approximately $2.6 \mathrm{~kb}$, referred to as DNA-A and DNA-B). Since the first reports of tomato diseases probably associated with begomoviruses in Brazil in the 1960s [1, 5], a complex of more than 20 begomoviruses has been described on tomato in Latin America and the Caribbean [3].

In July 2010, leaf samples from tomato plants showing severe symptoms of leaf curling and yellowing resembling tomato yellow leaf curl disease (TYLCD) were collected in French Guiana (Table 1) and preserved by dehydration using anhydrous calcium chloride. Total DNA was extracted using a DNeasy Plant Mini Kit (QIAGEN). Viral genomes were amplified by rolling-circle amplification using Phi29 DNA polymerase [7]. Amplified products were digested with $\mathrm{XbaI}$ and $\mathrm{NcoI}$ endonucleases. The monomeric full-length DNA-A and DNA-B molecules obtained $(\sim 2.6 \mathrm{~kb})$ were purified and ligated into the pGEM-3Zf vector (Promega). The ligated products were then cloned into Escherichia coli (JM 109). The isolated genomes were completely sequenced by primer walking (Macrogen), and contigs were assembled with DNA Baser v.2.91 (Heracle BioSoft). First, DNA-A and DNA-B nucleotide sequences were subjected to a BLAST search for preliminary species 
Table 1 Geographical origin of tomato samples and description of French Guiana isolates of tomato chlorotic mottle Guyane virus (ToCMoGFV)

\begin{tabular}{|c|c|c|c|c|c|c|}
\hline \multirow{2}{*}{$\begin{array}{l}\text { Date of sampling } \\
\text { (dd/mm/yyyy) }\end{array}$} & \multirow[t]{2}{*}{ Locality $^{\#}$} & \multicolumn{2}{|c|}{ GPS coordinates } & \multirow[t]{2}{*}{ Isolate acronym } & \multirow{2}{*}{$\begin{array}{l}\text { DNA-A GenBank } \\
\text { accession no. }\end{array}$} & \multirow{2}{*}{$\begin{array}{l}\text { DNA-B GenBank } \\
\text { accession no. }\end{array}$} \\
\hline & & Latitude & Longitude & & & \\
\hline 06-07-2009 & Stoupan & 4.728303 & -52.324996 & [GF:Sto1:GF435:09] & KR263179 & KR263178 \\
\hline 06-07-2009 & Stoupan & 4.728303 & -52.324996 & [GF:Sto2:GF462:09] & - & KR263175 \\
\hline 06-07-2009 & Stoupan & 4.728303 & -52.324996 & [GF:Sto3:GF453:09] & - & KR263176 \\
\hline 06-07-2009 & Montsinéry & 4.891269 & -52.493338 & [GF:Mon1:GF451:09] & KR263180 & KR263174 \\
\hline 06-07-2009 & Montsinéry & 4.891269 & -52.493338 & [GF:Mon2:GF455:09] & KR263181 & KR263172 \\
\hline 06-07-2009 & Montsinéry & 4.891269 & -52.493338 & [GF:Mon3:GF436:09] & - & KR263173 \\
\hline 08-07-2009 & Kourou & 5.154824 & -52.645413 & [GF:Kou:GF454:09] & - & KR263177 \\
\hline
\end{tabular}

\# Each sample corresponds to a distinct leaf from a different plant

assignment. Multiple sequences were aligned by the MUSCLE alignment method, and maximum-likelihood (ML) phylogenetic trees were constructed by the PHYML method implemented in MEGA v.6.06 [14]. Pairwise identity comparisons of nucleotide sequences were performed with pairwise deletion of gaps using SDT v1.2 [10].

Three DNA-A and seven DNA-B nucleotide sequences were obtained, with features typical of New World bipartite begomoviruses (Table 1). DNA-A components, 2631/2633 nucleotides in length, shared more than $99.8 \%$ nucleotide sequence identity. They had five open reading frames (ORFs): AV1 (249 aa; capsid protein [CP]) in the viral sense, and AC1 (344 aa; replication-associated protein [REP]), AC2 (130 aa; transcriptional activator protein [TrAP]), AC3 (132 aa; replication enhancer protein [REn]) and AC4 (85 aa; AC4 protein) in the complementary sense. The DNA-B components, 2603 nucleotides in length, shared more than $99.3 \%$ nucleotide sequence identity. They had two ORFs: BV1 (256 aa; nuclear shuttle protein [NSP]) in the viral sense and BC1 (293 aa; movement protein $[\mathrm{MP}])$ in the complementary sense. Both DNA components shared the conserved nonanucleotide motif (5'-TAATATTAC-3') as part of a stem-loop structure in the origin of replication (Supplementary Figure 1). The cognate DNA-A and DNA-B components had identical iterons, GGTGA, repeated two times just before the TATA-box. The corresponding iteron-related domain (IRD; Rep N-terminal domain interacting with ori-associated iterons [2]), was identified as MPPPKRFRIN.

The DNA-A and DNA-B nucleotide sequences are only distantly related to known New World bipartite begomoviruses. The DNA-A sequences share the highest nucleotide sequence identity (80\% and $79 \%$ ) with the Brazilian isolates of macroptilium yellow spot virus (MacYSV-[BR:Oaf25:11]; KC004133) and tomato chlorotic mottle virus (ToCMoV-[BR:Flo210:08]; KC706560), respectively (Fig. 1A). The DNA-B sequences share the highest nucleotide sequence identity (73\% and $72 \%$ ) with Brazilian isolates of soybean chlorotic spot virus (SBCSV-[BR:Jai9254:10]; JX122966) and tomato golden mosaic virus (TGMV-[BR:91/12], JF694491), respectively (Fig. 1B). According to the recently updated ICTV begomovirus species demarcation criteria (91\% DNA-A nucleotide sequence identity without gaps) [4]), these isolates should be assigned to a new species of tomato-infecting bipartite begomovirus, and we propose the name "tomato chlorotic mottle Guyane virus" (ToCMoGFV). ML trees confirmed that the complete nucleotide sequences of DNA-A (Fig. 1A) and DNA-B (Fig. 1B) of ToCMoGFV form a clear distinct clade among the current New World bipartite begomoviruses. Analysis of recombination using RDP4 [8] revealed no evidence of a recombination event in any of the genomic components.

In conclusion, our results show that ToCMoGFV is representative of a new lineage that is genetically isolated from the currently described New World bipartite begomoviruses in Latin America. Interestingly, the polyphagous invasive Middle East-Asia Minor 1 and Mediterranean cryptic species of $B$. tabaci, formerly known as B and Q biotypes were concomitantly detected with the disease in French Guiana (H. Delatte, unpublished results), further supporting the hypothesis that the sudden emergence of tomato-infecting begomoviruses in Latin America is mainly the result of the switch by indigenous viruses from uncultivated to cultivated host plants after the introduction and dissemination of polyphagous invasive vectors [1, 12, 13]. The natural host range of these tomato-infecting begomoviruses, the existence of undiscovered viral diversity in natural ecosystems, and the risk for crops are still open questions. 

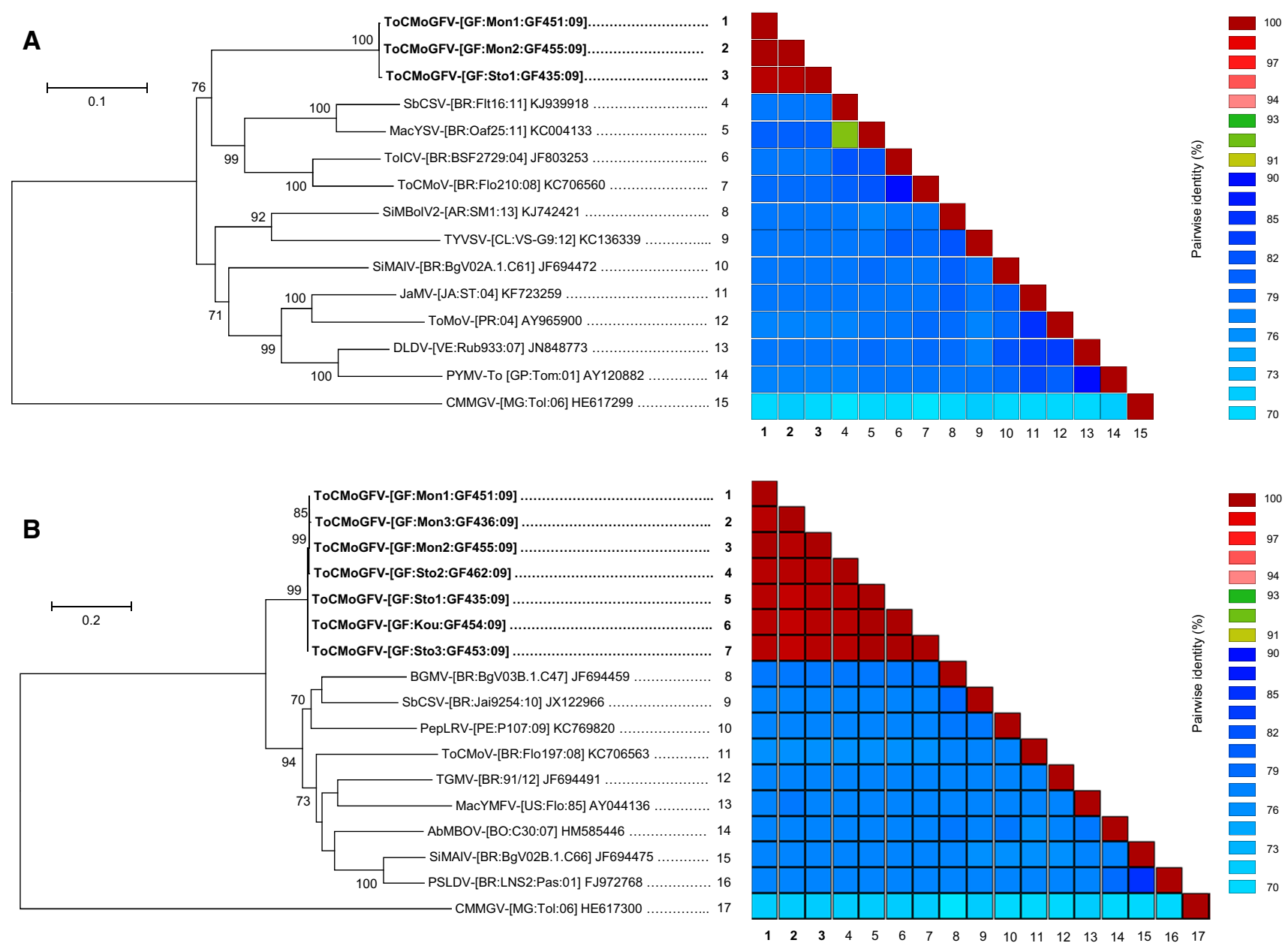

Fig. 1 Maximum-likelihood phylogenetic trees and colour-coded matrix of pairwise nucleotide sequence identity inferred from alignments of complete DNA-A (A) and DNA-B (B) sequences of ToCMoGFV and representative New World bipartite begomoviruses. Only bootstrap values at nodes higher than $70 \%$ are displayed (1000 replicates). The scale bar represents the genetic distance. The trees

Acknowledgments This study was funded by the European Union (FEDER), the Région Réunion and CIRAD.

\section{References}

1. Albuquerque LC, Varsani A, Fernandes FR, Pinheiro B, Martin DP, Ferreira PDO, Lemos TO, Inoue-Nagata AK (2012) Further characterization of tomato-infecting begomoviruses in Brazil. Arch Virol 157:747-752

2. Arguello-Astorga GR, Ruiz-Medrano R (2001) An iteron-related domain is associated to Motif 1 in the replication proteins of geminiviruses: identification of potential interacting amino acidbase pairs by a comparative approach. Arch Virol 146:1465-1485

3. Brown JK, Fauquet CM, Briddon RW, Zerbini M, Moriones E, Navas-Castillo J (2012) Geminiviridae. In: King AMQ, Adams MJ, Carstens EB, Lefkowitz EJ (eds) Virus Taxonomy, Ninth Report of the International Committee on Taxonomy of Viruses. Elsevier/Academic Press, London, pp 351-373 were rooted with sequences of the Old World bipartite CMMGV. The matrix uses a discontinuous range of three shades of colour (red, green and blue) differentiating two cutoff values representing the strain (93-94 \%, red-green) and the species (90-91\%, blue-green) demarcation thresholds of begomoviruses [4]. For begomovirus acronyms, see Supplementary Table 1 (colour figure online)

4. Brown JK, Zerbini FM, Navas-Castillo J, Moriones E, RamosSobrinho R, Silva JCF, Fiallo-Olive E, Briddon RW, HernandezZepeda C, Idris A, Malathi VG, Martin DP, Rivera-Bustamante R, Ueda S, Varsani A (2015) Revision of Begomovirus taxonomy based on pairwise sequence comparisons. Arch Virol 160:1593-1619

5. Castillo-Urquiza GP, Beserra JE, Bruckner FP, Lima ATM, Varsani A, Alfenas-Zerbini P, Zerbini FM (2008) Six novel begomoviruses infecting tomato and associated weeds in Southeastern Brazil. Arch Virol 153:1985-1989

6. Fernandes FR, de Albuquerque LC, de Britto Giordano L, Boiteux LS, de Avila AC, Inoue-Nagata AK (2008) Diversity and prevalence of Brazilian bipartite begomovirus species associated to tomatoes. Virus Genes 36:251-258

7. Inoue-Nagata AK, Albuquerque LC, Rocha WB, Nagata T (2004) A simple method for cloning the complete begomovirus genome using the bacteriophage phi29 DNA polymerase. J Virol Methods 116:209-211

8. Martin DP, Lemey P, Lott M, Moulton V, Posada D, Lefeuvre P (2010) RDP3: a flexible and fast computer program for analyzing recombination. Bioinformatics 26:2462-2463 
9. Melgarejo TA, Kon T, Rojas MR, Paz-Carrasco L, Zerbini FM, Gilbertson RL (2013) Characterization of a new world monopartite begomovirus causing leaf curl disease of tomato in Ecuador and Peru reveals a new direction in geminivirus evolution. J Virol 87:5397-5413

10. Muhire BM, Varsani A, Martin DP (2014) SDT: a virus classification tool based on pairwise sequence alignment and identity calculation. PLoS ONE 9:e108277

11. Ribeiro SG, Ambrozevicius LP, Avila AC, Bezerra IC, Calegario RF, Fernandes JJ, Lima MF, deMello RN, Rocha H, Zerbini FM (2003) Distribution and genetic diversity of tomato-infecting begomoviruses in Brazil. Arch Virol 148:281-295

12. Rocha CS, Castillo-Urquiza GP, Lima ATM, Silva FN, Xavier CAD, Hora BT, Beserra JEA, Malta AWO, Martin DP, Varsani
A, Alfenas-Zerbini P, Mizubuti ESG, Zerbini FM (2013) Brazilian begomovirus populations are highly recombinant, rapidly evolving, and segregated based on geographical location. J Virol 87:5784-5799

13. Rojas MR, Hagen C, Lucas WJ, Gilbertson RL (2005) Exploiting chinks in the plant's armor: evolution and emergence of geminiviruses. Annu Rev Phytopathol 43:361-394

14. Tamura K, Stecher G, Peterson D, Filipski A, Kumar S (2013) MEGA6: Molecular Evolutionary Genetics Analysis Version 6.0. Mol Biol Evol 30:2725-2729 